\title{
Tipe Habitat Kesukaan Rusa Timor (Rusa timorensis) di Hutan Wanagama I
}

\author{
Habitat Type Preferences of Timor Deer (Rusa timorensis) in Wanagama I Forest \\ Danang Wahyu Purnomo*, Djuwantoko, dan Satyawan Pudyatmoko \\ Laboratorium Satwa Liar Fakultas Kehutanan Universitas Gadjah Mada, Yogyakarta \\ E-mail: dnabdz@yahoo.com*Penulis untuk korespondensi
}

\begin{abstract}
Wanagama I Forest (599.7 ha) is a research and education forest which is the habitat of Timor Deer (Rusa timorensis). The deer population has been breeding naturally. The habitat changes have affected to the deer in selecting the resources in its habitat and have caused the deer moving out from the forest to the more strategic area, i.e. agricultural and settlement. We suspected that the case happened because of the habitat quality degradation in the forest. The research was aimed to identify habitat types preferred by deer that were called Habitat Preference. Habitat preference was analyzed by habitat selection that was estimated using habitat-categorizing approaches (Alldredge, Thomas, and Mcdonald, 1998; Manly et al., 2002). Habitat selection was identified by chi-square test and the preference index was estimated by selection ratio index. The result of habitat-categorizing analysis showed that there was a habitat selection by the deer (chi-square test $X^{2}=15.23, \alpha=0.05$ ). Block 5 (selection standardized index, $B=0.220)$, Block $17(B=0.212)$, and Block $14(B=0.149)$ were the habitat types which had high probability selected by the deer for their activities.
\end{abstract}

Key words: Habitat preference, Timor Deer, Wanagama Forest

\begin{abstract}
Abstrak
Hutan Wanagama I $(599,7$ ha) merupakan hutan pendidikan dan penelitian yang menjadi habitat Rusa Timor (Rusa timorensis). Populasi Rusa Timor berkembang biak secara alami. Perubahan habitat yang terjadi mempengaruhi perilaku rusa dalam memilih sumberdaya di dalamnya. Populasi rusa bergerak keluar dari hutan menuju tempat-tempat yang lebih strategis seperti lahan pertanian dan pemukiman. Keadaan tersebut terjadi akibat adanya penurunan kualitas habitat di dalam hutan. Penelitian ini bertujuan untuk mengidentifikasi tipe habitat kesukaan rusa. Tipe habitat kesukaan dianalisis dengan metode seleksi habitat menggunakan pendekatan habitat-categorizing (Alldredge, Thomas, dan Mcdonald, 1998; Manly et al., 2002). Seleksi habitat diidentifikasi menggunakan chi-square test, sedangkan indeks kesukaan diestimasi menggunakan indeks rasio seleksi. Hasil analisis habitat-categorizing menunjukkan adanya seleksi terhadap tipe habitat (chi-square test $X^{2}=15,23, \alpha=0,05$ ). Petak 5 (indeks standar seleksi $B=0,220)$, Petak $17(B=0,212)$, dan Petak $14(B=0,149)$ berturut-turut merupakan tipe habitat kesukaan yang memiliki peluang tinggi untuk dipilih rusa untuk beraktivitas.
\end{abstract}

Kata kunci: Habitat kesukaan, Rusa Timor, Hutan Wanagama I

Diterima: 26 Desember 2009, disetujui: 01 Juni 2010

\section{Pendahuluan}

Hutan Wanagama I seluas 599,7 ha merupakan hutan penelitian dan pendidikan yang di dalamnya terdapat sekitar 37 ekor rusa (Rusa timorensis) yang berkembang secara alami (Purnomo, 2003; Supraptomo, 2006). Menurut IUCN (2010), Rusa timorensis yang dikenal pula dengan nama Javan Deer atau Rusa Deer
(Cervus timorensis) secara global status konservasinya termasuk rentan (vulnerable $\mathrm{Cl}$ ver 3.1). Dinamika lingkungan yang terjadi mengakibatkan perubahan kondisi habitat di dalam hutan sehingga populasi rusa bergeser menuju kawasan yang lebih strategis di luar hutan (Zein dan Achmad, 2001; Suhadi dan Hadi). Menurut Dewi (2006), sebagian populasi rusa di Hutan Wanagama I menjadi hama bagi 
tanaman pertanian sekitar kawasan. Beberapa petani memburu rusa sampai dalam kawasan hutan. Hal ini jelas menjadi ancaman bagi kelestarian populasi Rusa Timor.

Berdasarkan beberapa kenyataan tersebut perlu segera dilakukan tindakan untuk kelestarian rusa di Hutan Wanagama I. Sistem pengelolaan rusa yang mengakomodasi kepentingan manajerial dan kepentingan masyarakat setempat merupakan langkah paling tepat mengatasi permasalahan di atas. Pergeseran pemanfaatan sumberdaya (resources) yang terjadi sangat mungkin berkaitan dengan perubahan ketersediaannya di dalam hutan (Djuwantoko dan Purnomo, 2008). Oleh karena itu, perlu dilakukan identifikasi habitat kesukaan Rusa Timor. Kondisi Hutan Wanagama I terdiri dari beragam tipe vegetasi perlu dianalisis dalam kaitannya dengan penyediaan kebutuhan sumberdaya (resources) bagi rusa. Tujuan penelitian ini adalah untuk mengetahui tipe-tipe vegetasi yang menjadi habitat preference Rusa Timor di Hutan Wanagama I.

\section{Tipe Habitat Rusa Timor}

Tipe habitat merupakan sebuah istilah yang dikemukakan oleh Doubenmire (1968) yang hanya berkenaan dengan tipe asosiasi vegetasi dalam suatu kawasan atau potensi vegetasi yang mencapai suatu tingkat klimaks. Tipe vegetasi dapat dikatakan sebagai manifestasi dari karakter habitat karena umumnya syarat-syarat hidup suatu jenis satwa selalu melibatkan aspek vegetasi Dasmann (1981). Menurut Bailey (1984) tipe habitat dicirikan oleh vegetasi utama (primarily vegetasion) yang merupakan faktor kesejahteraan satwa (welfare factor). Struktur vegetasi dapat dikategorikan berdasarkan kenampakan vegetasi (physiognomy) (MuellerDombois dan Ellenberg, 1974).

Tipe-tipe vegetasi yang ada pada setiap petak di Hutan Wanagama I merupakan gambaran dari tipe-tipe habitat bagi Rusa Timor. Hutan Wanagama I terdiri dari beberapa petak vegetasi yang memiliki karakteristik vegetasi berbeda. Struktur dan komposisi vegetasi pada tiap-tiap petak beragam sesuai dengan usia tanam dan distribusi tanam dalam pengelolaannya. Rusa Timor memiliki peluang untuk memanfaatkan setiap tipe habitat yang ada dengan intensitas penggunaan yang sesuai kebutuhan hidupnya.

\section{Seleksi Habitat}

Seleksi (selection) merupakan proses satwa memilih komponen-komponen habitat yang digunakan (Johnson, 1980). Satwa memilih habitat melalui sebuah proses hierarkhi keruangan (Johnson, 1980; Hutto, 1985), yaitu: 1) Seleksi pada skala jelajah geografis; 2) Seleksi pada skala di mana satwa melakukan aktivitasnya (dalam home range); 3) Seleksi pada skala site khusus (specific site) atau untuk komponen tertentu dalam wilayah jelajah mereka; dan 4) Seleksi pada saat satwa memilih bagaimana mereka akan memperoleh sumberdaya dalam microsite-nya.

Tipe habitat tertentu khusus yang sering dikunjungi rusa dan memiliki tingkat pemanfaatan yang tinggi merupakan habitat kesukaan (habitat preference). Kesukaan habitat merupakan konsekuensi proses yang menghasilkan adanya penggunaan yang tidak proporsional terhadap beberapa sumberdaya, yang mana beberapa sumberdaya digunakan melebihi yang lain. Adanya proses memilih (selection) dengan proporsi yang berbeda pada setiap sumberdaya menyebabkan adanya habitat kesukaan. Menurut Johnson (1980) kesukaan (preference) adalah kemungkinan (likelihood) suatu sumberdaya untuk dipilih satwa di antara beberapa sumberdaya yang ada.

\section{Metode Penelitian}

\section{Lokasi dan Waktu Penelitian}

Penelitian ini dilakukan di kawasan Hutan Wanagama I Kabupaten Gunungkidul. Waktu pengambilan data lapangan adalah selama musim kemarau pada bulan Juli hingga awal November 2008, dan pengolahan data pada bulan Desember 2008 hingga April 2009.

\section{Alat dan Bahan}

Alat-alat dan bahan yang dibutuhkan dalam penelitian ini antara lain: Binokuler, Roll meter, Kompas, GPS, Kamera, Rangefinder, Hygrothermometer, Clinometer, Tabung Okuler, Density Board, Herbarium, Tallysheet, Peta Hutan Wanagama I, alat tulis. 


\section{Identifikasi Tipe Habitat}

Hutan Wanagama I memiliki beberapa petak vegetasi yang dibedakan menurut struktur dan komposisi vegetasi. Untuk menguji adanya tipe habitat yang berbeda dilakukan multivariate analysis of variance (MANOVA) terhadap beberapa variabel vegetasi pada tiap petak vegetasi. Pada tiap petak vegetasi dilakukan pengukuran variabel vegetasi. Plot-plot pengamatan ditempatkan secara sistematik dengan jarak antarplot 100 meter dan jarak antarjalur 200 meter pada masing-masing tipe habitat.

\section{Survey Populasi}

Pemanfaatan habitat oleh satwa diestimasi dengan pendekatan tidak langsung berupa jejak kaki dan kotoran rusa (Lavieren, 1982; Strien, 1983). Survei populasi dilakukan untuk identifikasi proporsi penggunaan suatu tipe habitat oleh satwa. Oleh karena sulitnya mengestimasi jumlah populasi berdasar jejak kaki atau kotoran, proporsi penggunaan rusa didekati dengan menghitung frekuensi kehadiran di suatu plot pengamatan. Plot-plot yang di dalamnya terdapat indikator populasi selanjutnya disebut used plot (u). Proporsi populasi terukur (observed) merupakan perbandingan jumlah used plot dan jumlah plot total.

Sebaran populasi rusa diidentifikasi menggunakan metode minimum convex polygon (Boitani dan Fuller, 2000). Titik-titik terluar posisi rusa dihubungkan dengan garis lurus hingga membentuk polygon. Poligon ini merupakan penaksiran lokasi aktivitas jelajah harian rusa. Untuk membantu pemetaan digunakan software ArcView GIS.

\section{Penentuan Seleksi Tipe Habitat}

Alldredge, Thomas, dan Mcdonald (1998) menjelaskan seleksi tipe habitat (habitatcategorizing) untuk menyatakan adanya beberapa tipe habitat yang berpeluang dipilih satwa. Analisis seleksi tipe habitat dilakukan dengan analisis chi square test untuk mendeteksi adanya sifat selektif rusa pada tipe habitat (Neu, Byers, dan Peek, 1974; Manly et al., 2002). Tahap selanjutnya adalah identifikasi tingkat kesukaan tipe habitat (habitat tipe preference) dengan menghitung nilai indeks seleksi (selection index) dan indeks standar seleksi (standarized index) (Manly et al., 2002).

\section{Analisis Data}

Analisis chi square test untuk membandingkan nilai obeserved proporsi kehadiran satwa dengan nilai expected habitat dengan rumus (Neu, Byers, dan Peek, 1974; Manly et al., 2002).

$$
\mathbf{X}^{2}=\Sigma\left[\left(\mathbf{O}_{\mathrm{i}}-\mathbf{E}_{\mathrm{i}}\right) / \mathbf{E}_{\mathrm{i}}\right]
$$

Keterangan:

$\mathrm{O}$ : frekuensi jumlah plot yang ada rusa (used plot) hasil obervasi (observed)

E :frekuensi yang diharapkan (expected) (proporsi luas $\mathrm{x}$ total used plot)

Apabila satwa terdeteksi mempunyai sifat selektif, selanjutnya dilakukan penaksiran tingkat kesukaan tipe habitat dengan nilai indeks seleksi (selection index) dan standar indeks seleksi (standarized index) (Manly et al., 2002).

$$
\hat{\mathbf{W}}=\mathbf{O}_{\mathbf{i}} / \boldsymbol{\pi}_{\mathbf{i}}
$$

Keterangan:

W : rasio seleksi (selection index)

$\mathrm{O}_{\mathrm{i}}$ : proporsi plot di tipe habitat i yang ada rusa (used plot)

$\pi_{\mathrm{i}}$ : proporsi area tipe habitat $\mathrm{i}$ yang tersedia (availability)

Nilai indeks standar seleksi tiap tipe habitat merupakan indeks seleksi proporsional terhadap nilai indeks seleksi total. Nilai indeks standar seleksi menujukkan tingkat kesukaan (preference) tiap-tiap tipe habitat. Nilai convidence interval proporsi penggunaan dihitung dengan perhitungan Benferroni Convidence Limit, dengan rumus :

$$
\text { CI 95\% }=\hat{W}_{\mathrm{i}} \pm \mathbf{z}_{\alpha / 2} \cdot \sqrt{ }\left[\mathrm{O}_{\mathrm{i}}\left(\mathbf{1}-\mathrm{O}_{\mathrm{i}}\right) /\left(\mathrm{U}_{\mathrm{t}} \boldsymbol{\pi}_{\mathrm{i}}{ }^{2}\right)\right]
$$

Keterangan:

$\hat{\mathrm{W}} \quad$ : rasio seleksi (selection index)

$\mathrm{O}_{\mathrm{i}}$ : proporsi plot di tipe habitat i yang ada rusa (used plot)

$\mathrm{z}_{\alpha / 2}$ : nilai $\mathrm{z}$ tabel pada $(1-(\alpha / \mathrm{n}))=(1-(0.05 / \mathrm{n}))$, dengan $\mathrm{n}=$ jumlah tipe habitat

$\mathrm{U}_{\mathrm{t}} \quad$ : total jumlah plot yang ada rusa

$\pi_{\mathrm{i}}$ : proporsi area tipe habitat $\mathrm{i}$ yang tersedia (availability) 


\section{Hasil dan Pembahasan}

\section{Tipe Habitat Rusa Timor}

Kenampakan vegetasi Hutan Wanagama I dilihat dari 5 variabel: jumlah jenis pohon, kerapatan semak dan tumbuhan bawah, volume daun dan semak, penutupan tajuk, dan penutupan tumbuhan bawah. Variabel vegetasi merupakan komponen penting habitat yang dibutuhkan rusa. Menurut Higgins et al., (1994), beberapa aspek penting dalam menentukan kualitas habitat suatu satwa: komposisi jenis, distribusi spasial vertikal dan horisontal, variasi waktu temporal, bimasa, struktur tegakan, dan struktur lanskap. Tipe penutupan (cover type) seperti struktur vegetasi dan mikroklimat sangat berpengaruh dalam menentukan kesejahteraan satwa (Bailey, 1984).
Hasil MANOVA pada Tabel 1 menunjukkan nilai $\mathrm{F}$ test untuk Wilk's Lambda sebesar 4.646 dan tingkat signifikansi 0.000. Hal ini berarti terdapat hubungan antara 8 petak di Hutan Wanagama I dan 5 variabel habitat. Nilai tersebut menunjukkan bahwa variabel habitat pada setiap petak signifikan berbeda, sehingga dapat dikatakan bahwa terdapat keragaman tipe vegetasi yang dapat ditunjukkan pada tiap-tiap petak.

Unit-unit pengelolaan Hutan Wanagama I yang berupa petak-petak secara signifikan menghasilkan keragaman tipe vegetasi yang berbeda-beda. Kondisi tipe habitat pada suatu petak akan berbeda dengan petak lain dalam memberikan respons terhadap kebutuhan habitat rusa. Gambar 1 terlihat perbandingan proporsi variabel vegetasi tiap petak. Setiap variabel vegetasi memiliki keragaman pada setiap petak.

Tabel 1. Hasil Multivariate Tests Faktor Petak Terhadap Variabel Vegetasi.

\begin{tabular}{rlrrrrr}
\hline Effect & & \multicolumn{1}{c}{ Value } & \multicolumn{1}{c}{ F } & Hypothesis df & \multicolumn{1}{c}{ Error df } & \multicolumn{1}{c}{ Sig. } \\
\hline \hline Intercept & Pillai's Trace & 959 & $479.074(\mathrm{a})$ & 5.000 & 102.000 & 000 \\
& Wilks' Lambda & 041 & $479.074(\mathrm{a})$ & 5.000 & 102.000 & 000 \\
& Hotelling's Trace & 23.484 & $479.074(\mathrm{a})$ & 5.000 & 102.000 & 000 \\
& Roy's Largest Root & 23.484 & $479.074(\mathrm{a})$ & 5.000 & 102.000 & 000 \\
\hline Petak & Pillai's Trace & 1.072 & 4.133 & 35.000 & 530.000 & 000 \\
& Wilks' Lambda & 260 & 4.646 & 35.000 & 431.505 & 000 \\
& Hotelling's Trace & 1.747 & 5.011 & 35.000 & 502.000 & 000 \\
& Roy's Largest Root & 960 & $14.532(\mathrm{~b})$ & 7.000 & 106.000 & 000 \\
\hline \hline
\end{tabular}

a. Exact statistic

b. The statistic is an upper bound on $\mathrm{F}$ that yields a lower bound on the significance level

c. Design: Intercept+Petak

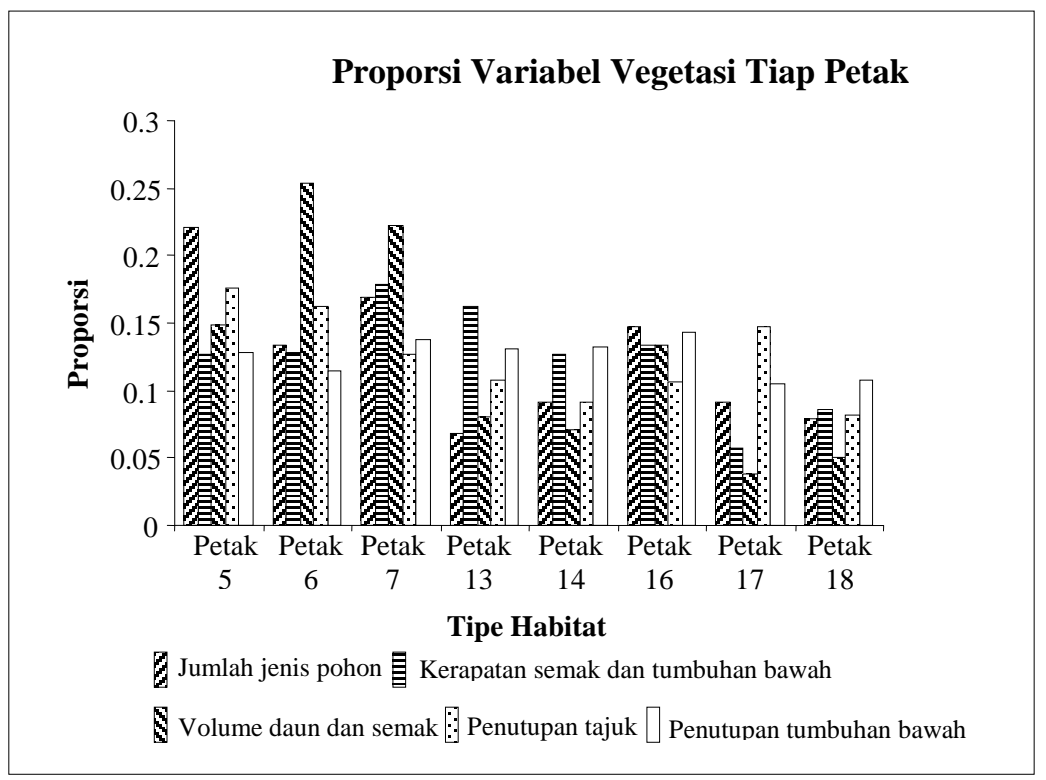

Gambar 1. Proporsi variabel vegetasi pada tiap tipe habitat. 


\section{Survei Populasi Rusa Timor}

Rusa Timor merupakan satwa yang sangat peka dengan kehadiran manusia dan tidak mudah ditemukan sehingga survei populasi Rusa Timor yang paling efektif adalah dengan mengidentifikasi jejak kaki dan kotorannya (Gambar 2). Populasi rusa bergerak meliputi seluruh wilayah Hutan Wanagama I, bahkan sebagian kecil keluar menuju lahan pertanian milik penduduk sekitar.

Hasil analisis minimum convex polygon menunjukkan wilayah jelajah harian populasi Rusa Timor di Hutan Wanagama I (Gambar 3). Berdasarkan data pengamatan, pola pergerakan kelompok rusa terdapat 3 kelompok besar, yaitu kelompok 1 di sekitar Petak 5, kelompok 2 di sekitar Kemuning dan Wonolagi, dan Kelompok 3 di sekitar Petak 14 dan 17. Setiap kelompok bergerak secara periodik menuju beberapa tempat di sekitarnya.

\section{Seleksi Tipe Habitat oleh Rusa Timor}

Rusa Timor menggunakan beberapa petak yang menyediakan berbagai sumber kehidupan seperti pakan, air, pelindung, dan mencari tempat yang sesuai untuk kehidupannya. Hasil analisis chi-square test menunjukkan terjadi seleksi tipe habitat oleh Rusa Timor dalam melakukan aktivitas hariannya (Tabel 2). Nilai $\mathrm{X}^{2}$ hitung sebesar 15,23; sementara $\mathrm{X}^{2}$ tabel 14.07 (pada taraf signifikan 0,05 ). Nilai $X^{2}$ hitung lebih besar dari $\mathrm{X}^{2}$ tabel sehingga Ho ditolak berarti ada seleksi habitat. Sementara itu, nilai standar seleksi (B) menunjukkan tingkat seleksi suatu tipe habitat (Manly et al., 2002). Terlihat dalam tabel bahwa Petak 5, Petak 17, dan Petak 14 berturut-turut memiliki indeks standar seleksi (B) sebesar 0,22; 0,212 dan 0,149 merupakan lokasi dengan kemungkinan yang besar untuk dipilih oleh rusa sebagai habitat kesukaannya.

Petak 5 memiliki struktur vegetasi paling rapat dibandingkan dengan kawasan lainnya (Anonim, 2005). Strata tajuk tegakan di Petak 5 merata dari bawah hingga ke atas dengan keragaman jenis pohon tinggi. Tumbuhan bawah Petak 5 didominasi oleh rumput waderan (Ageratum conyzoides) (Indek Nilai Penting/ $\mathrm{INP}=60,55$ ), kerinyu (Eupatorium odoratum) (INP $=46,21)$, dan alang-alang (Imperata cylindrica) (INP=45,58) (Supraptomo, 2006). Keragaman jenis rumput semakin bervariasi pada beberapa ruang terbuka semacam padang rumput dalam Petak 5. Jenis-jenis pohon didominasi oleh jenis kayu putih (Melaleuca leucadendron), akasia (Acacia mangium), mahoni (Swietenia macrophylla), jati (Tectona grandis), dan gliriside (Gliricidea $s p$ ) (Supraptomo, 2006).

Kerapatan semak dan tumbuhan bawah merupakan indikator kelimpahan sumber pakan bagi satwa termasuk rusa (Noon, 1981; Zein dan Achmad, 2001). Vegetasi rumput yang melimpah di Petak 5 sangat menunjang bagi ketersediaan pakan rusa. Jenis-jenis vegetasi pakan kesukaan Rusa Timor di Wanagama I di antaranya alang-alang (Imperata cylindrica) (Tingkat Kesukaan Pakan/TKP=0,67) dan rumput waderan (Ageratum conyzoides) (TKP=0,33) (Purnomo, 2003). Walaupun Rusa Timor merupakan jenis pemakan segala jenis rumput dan pucuk daun muda (Dradjat, 2002), rerumputan adalah pakan dominan di habitat alaminya. Analisis rumen terhadap Rusa Timor liar di hutan sclerophill New Caledonia mendapatkan hasil bahwa sekitar 64\% materi makanan berupa rerumputan asli setempat (Wichatitsky et al., 2005). Keberadaan alangalang yang dominan dengan biomassa tinggi telah mendorong Rusa Timor untuk mendiami padang rumput Kebar Papua secara kontinyu (Pattiselanno dan Arobaya, 2009).

Keragaman jenis pohon yang tinggi dapat meningkatkan variasi sumberdaya terutama kuantitas pakan dan ketersediaan tumbuhan penutup yang dibutuhkan satwa (Bailey, 1982; Higgins et al., 1994). Keragaman vegetasi berfungsi menjaga lingkungan, membuat keseimbangan komunitas satwa dan ekosistem di dalamnya (Bolen dan Robinson, 1995; Zein dan Achmad, 2001). Kondisi vegetasi Petak 5 yang heterogen mendorong Rusa Timor tinggal menetap untuk memenuhi kebutuhan hidupnya. Sebagaimana Rusa Timor di Kebar, selain memanfaatkan padang rumput juga menggunakan beberapa tipe habitat hutan primer dan hutan sekunder (Pattiselanno dan Arobaya, 2009).

Sungai Oyo yang melintas di Petak 5 merupakan sungai permanen yang menjadi sumber air utama bagi satwaliar termasuk rusa di 
Hutan Wanagama I. Walaupun rusa termasuk satwa yang tahan kekeringan (Dradjat, 2002), cenderung bergerak mendekati sumber air pada musim kemarau. Rusa Timor bertahan di sekitar sumber air seperti sungai dan mata air.
Keberadaan Sungai Apriri di Kebar sangat penting bagi kehidupan populasi Rusa Timor pada musim kemarau (Pattiselanno dan Arobaya, 2009).
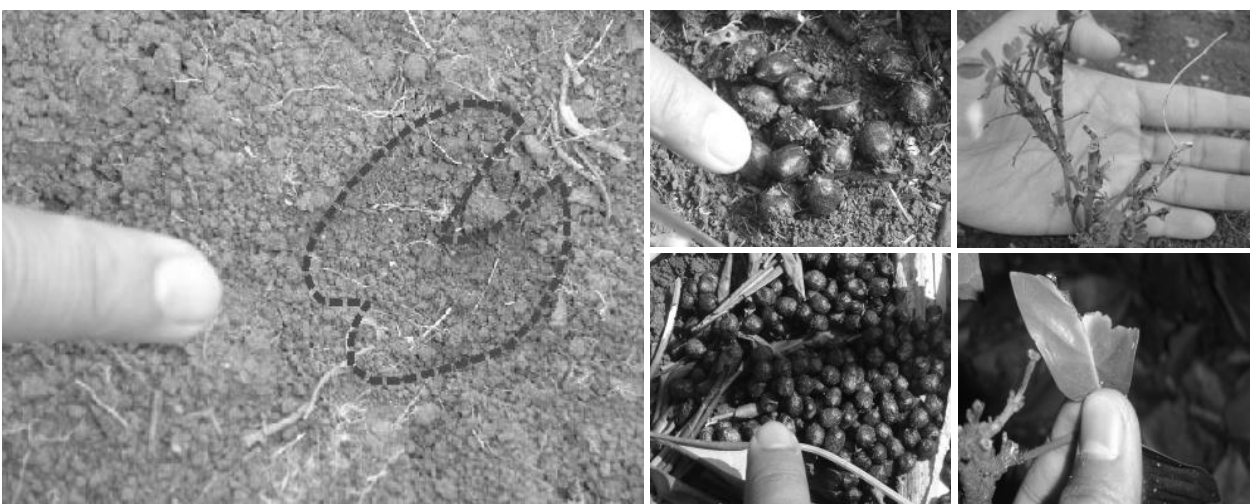

Gambar 2. Indikator populasi berupa jejak kaki, kotoran, dan sisa pagutan.

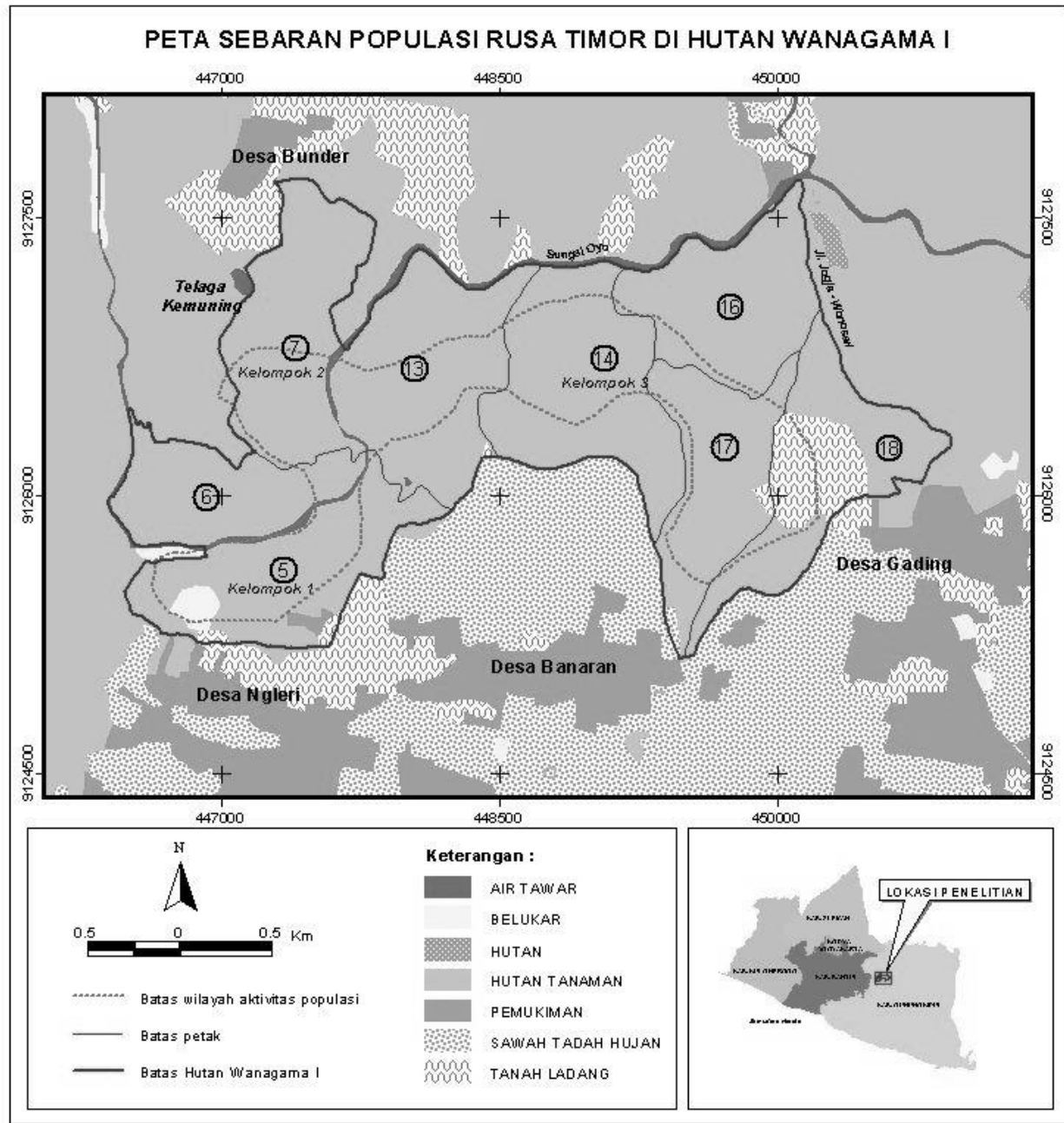

Gambar 3. Sebaran populasi Rusa Timor di Hutan Wanagama I. 
Purnomo et al.,

Tabel 2. Analisis Chi-SquareTest Untuk Menentukan Seleksi Habitat.

\begin{tabular}{|c|c|c|c|c|c|c|c|c|c|c|c|}
\hline \multirow[b]{2}{*}{ Lokasi } & \multirow{2}{*}{$\begin{array}{l}\text { Area } \\
\text { (Ha) }\end{array}$} & \multirow{2}{*}{$\begin{array}{c}\text { Proporsi } \\
\text { Aarea } \\
(\pi)\end{array}$} & \multirow{2}{*}{$\begin{array}{c}\Sigma \text { plot } \\
\text { Sampel }\end{array}$} & \multirow{2}{*}{$\begin{array}{c}\text { Used } \\
\text { Plot } \\
(\mathbf{u})\end{array}$} & \multirow{2}{*}{$\begin{array}{l}\text { Proporsi } \\
\text { Uused Plot } \\
\text { (O) }\end{array}$} & \multirow{2}{*}{$\begin{array}{l}\Sigma \text { used Plot } \\
\text { Harapan } \\
\text { (E) }\end{array}$} & \multirow{2}{*}{ 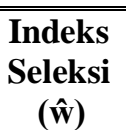 } & \multirow{2}{*}{$\begin{array}{c}\text { Indeks Standar } \\
\text { Seleksi } \\
\text { (B) }\end{array}$} & \multirow{2}{*}{$\begin{array}{l}\text { SE } \\
(\hat{\mathbf{w}})\end{array}$} & \multicolumn{2}{|c|}{ Bonferroni CI } \\
\hline & & & & & & & & & & Lower & Upper \\
\hline Petak 5 & 79,9 & 0,133 & 15 & 13 & 0,236 & 7,325 & 1,775 & 0,220 & 0,430 & 0,079 & 0,393 \\
\hline Petak 6 & 51,3 & 0,086 & 10 & 5 & 0,091 & 4,703 & 1,063 & 0,132 & 0,453 & 0,000 & 0,197 \\
\hline Petak 7 & 77,7 & 0,130 & 15 & 7 & 0,127 & 7,124 & 0,983 & 0,122 & 0,347 & 0,004 & 0,250 \\
\hline Petak 13 & 88,1 & 0,147 & 17 & 6 & 0,109 & 8,077 & 0,743 & 0,092 & 0,286 & 0,000 & 0,224 \\
\hline Petak 14 & 90,7 & 0,151 & 17 & 10 & 0,182 & 8,316 & 1,203 & 0,149 & 0,344 & 0,039 & 0,324 \\
\hline Petak 16 & 72 & 0,120 & 14 & 1 & 0,018 & 6,601 & 0,151 & 0,019 & 0,150 & 0,000 & 0,068 \\
\hline Petak 17 & 64 & 0,107 & 12 & 10 & 0,182 & 5,868 & 1,704 & 0,212 & 0,487 & 0,039 & 0,324 \\
\hline Petak 18 & 76,2 & 0,127 & 14 & 3 & 0,055 & 6,986 & 0,429 & 0,053 & 0,241 & 0,000 & 0,138 \\
\hline & $\begin{array}{l}599,9 \\
\end{array}$ & & $\overline{c 114}$ & $\overline{55}$ & & & 8,051 & 1,000 & & & \\
\hline
\end{tabular}

Keterangan:

$X^{2}=15,23$ dan $X^{2}$ tabel $=14,07(\alpha=0,05)$, maka ada seleksi terhadap beberapa tipe habitat.

Nilai $\alpha=0,05$ maka $0,05 / 8=0,00625$; maka convident limit $=0,99375 ; Z=2,74$.

\section{Simpulan dan Saran}

\section{Simpulan}

Rusa Timor melakukan seleksi habitat dalam aktivitas harian untuk memilih tipe habitat kesukaannya. Tipe habitat kesukaan Rusa Timor di Hutan Wanagama I berturut-turut antara lain Petak 5 (nilai standar seleksi/ $\mathrm{B}=0,22$ ), Petak 17 $(B=0,212)$, dan Petak $14 \quad(B=0,149)$. Ketiga lokasi tersebut memiliki peluang besar untuk dipilih rusa sebagai tempat beraktivitasnya.

\section{Saran}

Pelestarian populasi Rusa Timor di Hutan Wanagama I perlu ditingkatkan dengan cara menentukan zona inti perlindungan terutama pada tipe-tipe habitat yang disukai rusa. Penyelesaian masalah gangguan pertanian dapat ditekan melalui usaha perbaikan kualitas habitat terutama pada habitat kesukaan di dalam hutan.

\section{Ucapan Terima Kasih}

Penelitian ini merupakan pendalaman analisis dari tesis penulis pertama yang ditempuh pada Sekolah Pascasarjana Program Studi Ilmu Kehutanan Fakultas Kehutanan UGM. Penulis mengucapkan terima kasih kepada Laboratorium Satwaliar Fakultas Kehutanan UGM Yogyakarta atas bantuan fasilitas penelitian. Penulis secara khusus mengucapkan terima kasih kepada Prof. Chafid Fandeli, Seno Adi Subrata, S.Hut, M.Sc., drh. Subeno, M.Sc., Tetuko, S.Hut, dan Gilang Anggit Budaya atas bantuan dan kerjasamanya.

\section{Daftar Pustaka}

Alldredge, R., Thomas, D.L. dan McDonald, L.L. 1998. Survey and Comparison of Methods for Study of Resource Selection. J. of Agricultural, Biological, and Environmental Statistics, 3 (3): 237-253.

Anonim. 2005. Rencana dan Model Konservasi Ekosistem Hutan Melalui Pengelolaan Rusa Sistem Terbuka di Hutan Wanagama I. Balai Konsevasi Sumber Daya Alam DIY dan Fakultas Kehutanan Universitas Gadjah Mada. Yogyakarta.

Bailey, J. 1982. Principles of Wildlife Management. Mc.Graw-Hill Book Company. New York, St. Louis, Sydney, Tokyo, New Delhi.

Boitani, L. dan Fuller, T.K. 2000. Research Techniques in Animal Ecology: Controversions and Concequences. Columbia University Press. New York.

Bolen, E.G. dan Robinson, W.L. 1995. Wildlife Ecology and Management. Prentince Hall. New Jersey.

Dasmann, R.F. 1981. Widlife Biology. $2^{\text {nd }}$ ed. John Wiley \& Sons. New York.

Dewi, A.S. 2006. Studi Tingkat Kerugian Petani Oleh Rusa Jawa (Cervus timorensis Mul. \& Schl.) di Sekitar Petak 5 Hutan Wanagama I Kabupaten Gunungkidul. Skripsi tidak dipublikasikan. Fakultas Kehutanan Universitas Gadjah Mada. Yogyakarta.

Djuwantoko dan Purnomo, D.W. 2008. Penentuan Pakan Rusa Bawean dengan Analisis Kotoran, di Pulau Bawean. Biota, 13 (3): 175-181.

Doubenmire, R. 1968. Plant Communities: A Textbook of Plant Synecology. Harper and Row. New York.

Dradjat, A.S. 2002. Satwa Harapan Budidaya Rusa. Buku Ajar. Mataram, Mataram University Press. 
Higgins, K.F., Oldmayer, J.L., Jenkin, K.J., Clamby, G.K. dan Harlow, R.F. 1994. Vegetation Sampling and Measurement. In: Bookhaut, T.A. (Eds.). Research and Management Techniques for Wildlife and Habitats. Fifth ed. The Wildlife Society. USA.

Hutto, R.L. 1985. Habitat Selection By Nonbreeding, Migratory Land Birds. In: Cody, M.L. (Eds.), Habitat Selection in Selection in Birds. Academic Press. Orlando.

IUCN. 2010. IUCN Red List of Threatened Species. http://www.iucnredlist.org. 16/06/2010.

Johnson, D.H. 1980. The Comparison of Usage and Availability Measurements for Evaluating Resource Preference. Ecology. The Ecological Society of America.

Lavieren, L.P.V. 1983. Wildlife Management in the Tropics with Special Emphasis on South East Asia. A Guidebook for the Warden. Part 2. School of Environmental Conservation Management. Bogor.

Manly, B.F.J., McDonald, L.L., Thomas, D.L., McDonald, T.L. dan Erickson, W.P. 2002. Resource Selection by Animals Statistical Design and Analysis for Field Studies. $2^{\text {nd }}$ Edition. Kluwer academic Publishers. Dorcrecht, Boston, London.

Mueller-Dombois dan Ellenberg, H. 1974. Aims and Methods of Vegetation Ecology. John Wiley \& Sons. New York.

Neu, C.W., Byers, C.R. dan Peek, J.M. 1974. A Technique for Analysis of Utilization-Availability Data. The J. of Wildlife Management. 38 (3): $541-545$.

Noon, B.R. 1981. Techniques for Sampling Avian Habitat. In: Capen, D.E. (Eds). The Use of Multivariate Statistics in Studies of Wildlife Habitat. General Rednical Report RM-87. US Department of Agriculture, Forest Service.
Pattiselanno, F. dan Arobaya, A.Y.S. 2009. Grazing Habitat of the Rusa Deer (Cervus timorensis) in the Upland Kebar, Manokwari. Biodiversitas, 10 (3): $134-138$

Purnomo, D.W. 2003. Studi Jenis Pakan dan Tingkat Kesukaannya Pada Rusa Jawa (Cervus timorensis Mul. \& Schl) di Wanagama I Gunungkidul. Skripsi tidak dipublikasikan. Fakultas Kehutanan Universitas Gadjah Mada. Yogyakarta.

Strien, N.J.V. 1983. A Guide To the Tracks of Mammals of Western Indonesia. School of Environmental Conservation Management. Ciawi-Indonesia.

Suhadi dan Hadi, S.A. 2004. Sebaran Tumbuhan Bawah Bekas Injakan Banteng (Bos javanicus d'Alton), Kerbau Liar (Bubalus bubalis), dan Rusa (Cervus timorensis) di Taman Nasional Baluran. Biota, IX (2): 78-83.

Supraptomo, H. 2006. Home Range dan Kelimpahan Rusa Jawa (Cervus timorensis) di Wanagama I Gunungkidul. Skripsi tidak dipublikasikan. Fakultas Kehutanan Universitas Gadjah Mada. Yogyakarta.

Wichatitsky, M.D.G., Soubeyran, Y., Maillard, D. dan Duncan, P. 2005. The Diets of Introduced Rusa Deer (Cervus timorensis russa) in a Native Sclerophyll Forest and Native Rainforest of New Caledonia. New Zealand J. of Zoology, 32: $117-126$.

Zein, M.S.A. dan Achmad, S. 2001. Populasi, Pola Pertumbuhan dan Ektoparasit Rusa Tumor (Cervus timorensis macassaricus Heude, 1896) di Padang Savana Taman Nasional Rawa Aopa Watumohai, Propinsi Sulawesi Tenggara. Biota, VI (1): 9-16. 